\title{
ON THE HYERS-CULAM STABILITY OF SEXTIC FUNCTIONAL EQUATIONS IN $\beta$-HOMOGENEOUS PROBABILISTIC MODULAR SPACES
}

\author{
Yeol Je Cho, Mohammad Bagher Ghaemi, \\ Mehdi Choubin AND MADJID Eshaghi GoRdJI
}

Abstract. In this paper, we present a fixed point method to prove the generalized Hyers-Ulam stability of the systems of additive-quadratic-cubic functional equations with constant coefficients in $\beta$-homogeneous probabilistic modular spaces.

Mathematics subject classification (2010): Primary 39B52; Secondary 39B72, 47H09. equation.

Keywords and phrases: Fixed point method, Hyers-Ulam stability, modular spaces, sextic functional

\section{REFERENCES}

[1] J. Aczel And J. Dhombres, Functional Equations in Several Variables, Cambridge University Press, Cambridge, 1989.

[2] T. AOKI, On the stability of the linear transformation in Banach spaces, J. Math. Soc. Japan 2 (1950), 64-66.

[3] V. K. Balachandran, Topological Algebras, Narosa Publishing House, New Delhi, Madras, Bombay, Calcutta, London, 1999.

[4] L. CĂDARIU AND V. RADU, Fixed points and the stability of Jensen's functional equation, J. Inequal. Pure Appl. Math. 4, no. 1, Art. 4 (2003).

[5] Y. J. Cho, M. Eshaghi Gordu And S. Zolfaghari, Solutions and stability of generalized mixed type QC functional equations in random normed spaces, J. Inequal. Appl. Vol. 2010 (2010), Article ID 403101, 16 pp.

[6] Y. J. CHO AND R. SAADATI, Lattice non-Archimedean random stability of ACQ functional equations, Advan. in Diff. Equat. 2011, 2011:31.

[7] P. W. Cholewa, Remarks on the stability of functional equations, Aequat. Math. 27 (1984), 76-86.

[8] S. CZERwiK, On the stability of the quadratic mapping in normed spaces, Abh. Math. Sem. Univ. Hamburg 62 (1992), 59-64.

[9] A. Ebadian, A. NAJATI AND M. E. GoRDJi, On approximate additive-quartic and quadratic-cubic functional equations in two variables on abelian groups, Results. Math. DOI 10.1007/s00025-0100018-4 (2010).

[10] A. Ebadian, N. Ghobadipour And M. E. Gordu, A fixed point method for perturbation of bimultipliers and Jordan bimultipliers in $C^{*}$-ternary algebras, J. Math. Phys. 51 (2010), 10 pp., doi:10.1063/1.3496391.

[11] M. Eshaghi Gordji, Y. J. Cho, M. B. Ghaemi And H. Majani, Approximately quintic and sextic mappings from $r$-divisible groups into Serstnev probabilistic Banach spaces: fixed point method, Discrete Dynamics in Nature and Society, Vol. 2011, Article ID 572062, 16 pp.

[12] K. Fallahi And K. Nourouzi, Probabilistic modular spaces and Linear operators, Acta Appl Math. 105 (2009), 123-140. 
[13] Z. GajdA, On stability of additive mappings, Internat. J. Math. Math. Sci. 14 (1991), 431-434.

[14] P. GǍvrUtA, A generalization of the Hyers-Ulam-Rassias stability of approximately additive mappings, J. Math. Anal. Appl. 184 (1994), 431-436.

[15] P. GǍvruta ANd L. GǍVRUtA, A new method for the generalized Hyers-Ulam-Rassias stability, Int. J. Nonlinear Anal. Appl. 1 (2010), 11-18.

[16] M. GRabiec, Y. J. Cho And V. Radu, On Nonsymmetric Topological and Probabilistic Structures, Nova Science Publishers, Inc., New York, 2006.

[17] M. B. Ghaemi, M. E. Gordui And H. Majani, Approximately quintic and sextic mappings on the probabilistic normed spaces, Preprint.

[18] M. E. GordJi, Stability of a functional equation deriving from quartic and additive functions, Bull. Korean Math. Soc. 47 (2010), 491-502.

[19] M. E. GoRdJI AND M. B. SAVADKOUHI, Stability of a mixed type cubic-quartic functional equation in non-Archimedean spaces, Appl. Math. Lett. 23 (2010), 1198-1202.

[20] M. E. Gordji, M. B. Ghaemi, S. K. Gharetapeh, S. Shams and A. Ebadian, On the stability of $\mathrm{J}^{*}$-derivations, J. Geom. Phys. 60 (2010), 454-459.

[21] M. E. Gordui, S. Kaboli Gharetapeh, C. Park and S. Zolfaghri, Stability of an additivecubic-quartic functional equation, Advances in Differ. Equat. Vol. 2009, Article ID 395693, 20 pp.

[22] M. E. Gordji, S. K. Gharetapeh, J. M. Rassias and S. Zolfaghari, Solution and stability of a mixed type additive, quadratic and cubic functional equation, Advances in differ. Equat. Vol. 2009, Article ID 826130, 17 pp.

[23] M. E. GorduI AND H. KhOdAeI, Solution and stability of generalized mixed type cubic, quadratic and additive functional equation in quasi-Banach spaces, Nonlinear Anal. 71 (2009), 5629-5643.

[24] M. E. Gordu And H. KhodaeI, On the generalized Hyers-Ulam-Rassias stability of quadratic functional equations, Abstr. Appl. Anal. Vol. 2009, Article ID 923476, 11 pp.

[25] M. E. GorduI AND H. KHODAEI, The fixed point method for fuzzy approximation of a functional equation associated with inner product spaces, Discr. Dynam. in Nature and Soc. Vol. 2010, Article ID $140767,15 \mathrm{pp}$.

[26] M. E. Gordji, H. Khodaei And R. Khodabakhsh, General quartic-cubic-quadratic functional equation in non-Archimedean normed spaces, U.P.B. Sci. Bull., Series A 72 (2010), 69-84.

[27] M. E. Gordui AND A. NAJATI, Approximately $J^{*}$-homomorphisms: A fixed point approach, J. Geom. Phys. 60 (2010), 809-814.

[28] D. H. HYERS, On the stability of the linear functional equation, Proc. Natl. Acad. Sci. USA 27 (1941), 222-224.

[29] D. H. Hyers, G. Is AC AND TH. M. RAssias, Stability of Functional Equations in Several Variables, Birkhäuser, Basel, 1998.

[30] K. W. JUn AND H. M. KIM, The generalized Hyers-Ulam-Rassias stability of a cubic functional equation, J. Math. Anal. Appl. 274 (2002), 867-878.

[31] K. W. Jun, H. M. Kim AND I. S. Chang, On the Hyers-Ulam stability of an Euler-Lagrange type cubic functional equation, J. Comput. Anal. Appl. 7 (2005), 21-33.

[32] S. M. Jung, Hyers-Ulam-Rassias Stability of Functional Equations in Mathematical Analysis, Hadronic Press Inc., Palm Harbor, Florida, 2001.

[33] S. M. Jung, Hyers-Ulam-Rassias stability of Jensen's equation and its application, Proc. Amer. Math. Soc. 126 (1998), 3137-3143.

[34] S. M. Jung, Stability of the quadratic equation of Pexider type, Abh. Math. Sem. Univ. Hamburg 70 (2000), 175-190.

[35] S. M. JUnG AND J. M. RASSIAS, A fixed point approach to the stability of a functional equation of the spiral of Theodorus, Fixed Point Theory Appl. Vol. 2008, Article ID 945010, 7 pp.

[36] P. KannapPan, Quadratic functional equation and inner product spaces, Results Math. 27 (1995), $368-372$. 
[37] H. A. KENARY AND Y. J. CHO, Stability of mixed additive-quadratic Jensen type functional equation in various spaces, Comput. Math. Appl. 61 (2011), 2704-2724.

[38] M. A. Khamsi, Quasicontraction Mapping in modular spaces without $\Delta_{2}$-condition, Fixed Point Theory Appl. Vol. (2008), Artical ID 916187, 6 pp.

[39] H. Khodaei, M. Eshaghi Gordji, S. S. Kim And Y. J. CHo, Approximation of radical functional equations related to quadratic and quartic mappings, J. Math. Anal. Appl. 397 (2012), 284-297.

[40] H. KHODAEI AND TH. M. RAssias, Approximately generalized additive functions in several variables, Internat. J. Nonlinear Anal. Appl. 1 (2010), 22-41.

[41] S. Koshi, T. Shimogaki, On F-norms of quasi-modular spaces, J. Fac. Sci. Hokkaido Univ. Ser. I 15 (1961), 202-218.

[42] M. KRBEC, Modular interpolation spaces, Z. Anal. Anwendungen 1 (1982), 25-40.

[43] S. H. LeE, S. M. Im And I. S. Hawng, Quartic functional equation, J. Math. Anal. Appl. 307 (2005), 387-394.

[44] W. A. Luxemburg, Banach function spaces, Ph. D. thesis, Delft Univrsity of Technology, Delft, The Netherlands, 1959.

[45] L. Maligranda, Orlicz. Spaces and Interpolation, in: Seminars in Math., Vol. 5, Univ. of Campinas, Brazil, 1989.

[46] K. Menger, Statistical metrics, Proc. Natl. Acad. Sci. USA 28 (1942), 535-537.

[47] M. Моhammadi, Y. J. Cho, C. Park, P. Vetro And R. SAadati, Random stability of an additive-quadratic-quartic functional equation, J. Inequal. Appl. Vol. 2010, Article ID 754210, 18 pp.

[48] J. Musielak, Orlicz Spaces and Modular Spaces, in: Lecture Notes in Math. Vol. 1034, SpringerVerlag, Berlin, 1983.

[49] A. NAJATI, Hyers-Ulam-Rassias stability of a cubic functional equation, Bull. Korean Math. Soc. 44 (2007), 825-840.

[50] H. Nakano, Modulared Semi-Ordered Linear Spaces, in: Tokyo Math. Book Ser., Vol. 1, Maruzen Co., Tokyo, 1950.

[51] K. Nourouzi, Probabilistic modular spaces, Further Progress in Analysis, World Sci. Publ., Hackensack, 814-818, 2009.

[52] W. Orlicz, Collected Papers, Vols. I, II, PWN, Warszawa, 1988.

[53] C. PARK, On an approximate automorphism on a $C^{*}$-algebra, Proc. Amer. Math. Soc. 132 (2004), 1739-1745.

[54] C. PARK, Y. J. CHO AND H. A. KenARY, Orthogonal stability of a generalized quadratic functional equation in non-Archimedean spaces, J. Comput. Anal. Appl. 14(2012), 526-535.

[55] C. PARK And M. E. Gordji, Comment on Approximate ternary Jordan derivations on Banach ternary algebras, [Bavand Savadkouhi et al. J. Math. Phys. 50, 042303 (2009)], J. Math. Phys. 51, 044102 (2010), 7 pp.

[56] C. PARK AND A. NAJATI, Generalized additive functional inequalities in Banach algebras, Int. J. Nonlinear Anal. Appl. 1 (2010), 54-62.

[57] C. PARK AND TH. M. RASSiAs, Isomorphisms in unital $C^{*}$-algebras, Internat. J. Nonlinear Anal. Appl. 1 (2010), 1-10.

[58] C. PARK AND J. M. RASSIAS, Stability of the Jensen-type functional equation in $C^{*}$-algebras: a fixed point approach, Abstr. Appl. Anal. Vol. 2009, Article ID 360432, 17 pp.

[59] TH. M. Rassias, On the stability of the linear mapping in Banach spaces, Proc. Amer. Math. Soc. 72 (1978), 297-300.

[60] TH. M. RAssias, On the stability of functional equations in Banach spaces, J. Math. Anal. Appl. 251 (2000), 264-284.

[61] TH. M. RASSIAS AND P. ŠEMRL, On the behaviour of mappings which do not satisfy Hyers-Ulam stability, Proc. Amer. Math. Soc. 114 (1992), 989-993. 
[62] R. SAADATI, Y. J. ChO AND J. VAHIDI, The stability of the quartic functional equation in various spaces, Comput. Math. Appl. 60 (2010), 1994-2002.

[63] GH. SAdeghi, A fixed point approach to stability of functional equations in modular spaces, Bull. Malays. Math. Sci. Soc. (to appear).

[64] GH. SADEGHI, On the orthogonal stability of the pexiderized quadratic equations in modular spaces, preprint.

[65] F. Skof, Propriet locali e approssimazione di operatori, Rend. Sem. Mat. Fis. Milano. 53 (1983), $113-129$.

[66] Ph. Turpin, Fubini inequalities and bounded multiplier property in generalized modular spaces, Comment. Math., Tomus specialis in honorem Ladislai Orlicz I (1978), 331-353.

[67] S. M. Ulam, Problems in Modern Mathematics, Chapter VI, Sci. Ed., Wiley, New York, 1964.

[68] S. Yamamuro, On conjugate spaces of Nakano spaces, Trans. Amer. Math. Soc. 90(1959) 291-311. 